Research Article

\title{
Brönsted Acid of Keggin Type Polyoxometalate Catalyzed Pinacol Rearrangement
}

\author{
Aldes Lesbani ${ }^{1,2}$ *, Risfidian Mohadi 1 \\ ${ }_{1}^{1}$ Departement of Chemistry, Faculty of Mathematic and Natural Sciences, Sriwijaya University, \\ Jl. Raya Palembang-Prabumulih Km.32, Ogan Ilir 30662, Sumatera Selatan, Indonesia \\ ${ }^{2}$ Laboratory of Graduate School Program, Sriwijaya University, Jl. Padang Selasa, Palembang \\ 30129, Sumatera Selatan, Indonesia
}

Received: 21st January 2013; Revised: 21st April 2014; Accepted: 3rd May 2014

\begin{abstract}
Keggin type polyoxometalates $\mathrm{K}_{4}\left[\mathrm{a}-\mathrm{SiW}_{12} \mathrm{O}_{40}\right]$ was synthesized and transformed to $\mathrm{H}_{4}\left[\mathrm{a}-\mathrm{SiW}_{12} \mathrm{O}_{40}\right]$. Both catalysts have been used for pinacol rearrangement in toluene at $373{ }^{\circ} \mathrm{K}$. The results showed that reaction of pinacol rearrangement did not proceed using $\mathrm{K}_{4}\left[\mathrm{a}-\mathrm{SiW}_{12} \mathrm{O}_{40}\right]$ as catalyst. The extent reaction time until $20 \mathrm{~h}$ also did not produce pinacolone as main product. By using $\mathrm{H}_{4}\left[\mathrm{a}-\mathrm{SiW}_{12} \mathrm{O}_{40}\right]$ as catalyst at $1 \mathrm{~h}$ reaction time gave conversion $100 \%$ with formation of pinacolone $72 \%$. The reaction produce $27 \%$ of 2,3-dimethyl-1,3-butadiene as byproduct and $99 \%$ carbon balance for the reaction. This phenomenon indicated the Brönsted acid is a key role for catalytic reaction of pinacol rearrangement to pinacolone. (c) 2014 BCREC UNDIP. All rights reserved
\end{abstract}

Keywords: Brönsted acid; Keggin type polyoxometalate; pinacol rearragement

How to Cite: Lesbani, A., Mohadi, R., (2014). Brönsted Acid of Keggin Type Polyoxometalate Catalyzed Pinacol Rearrangement. Bulletin of Chemical Reaction Engineering \& Catalysis, 9 (2): 136-141. (doi:10.9767/bcrec.9.2.6074.136-141)

Permalink/DOI: http://dx.doi.org/10.9767/bcrec.9.2.6074.136-141

\section{Introduction}

The pinacol rearrangement is a simple wellknown reaction under acid condition to give pinacolone as main product [1]. The mechanisms of pinacol to pinacolone are elimination of water and skeletal rearrangement of $1,2-$ diols in acid medium [2]. The reaction is usually carried out in the presence of strong inorganic liquid acid such as hydrochloric acid, sulphuric acid, and nitric acid [3]. The main problems using these catalysts are handling reagents and corrosive. Recently, the development of solid acid catalyst is sharply increased in order to obtain stable catalyst, non-corrosive, easy to handle, eco friendly, and reusability. Several solid acid catalysts have been tasted

* Corresponding Author.

E-mail: aldeslesbani@yahoo.com (A. Lesbani) for pinacol to pinacolone rearrangement. Molecular sieve of aluminophosphate with different crystalline structures were successfully catalyzed pinacol rearrangement with two main products [4]. Aluminosilicate material such as zeolite is also catalyzed pinacol to pinacolone rearrangement [5]. Both molecular sieve and aluminosilicate materials are Lewis acid catalyzed pinacol rearrangement. Solid acid catalyst with metal-oxygen cluster that we called "polyoxometalate compounds" is investigated as acid catalyzed pinacol rearrangement [6]. These catalysts have already been introduced into large scales industrial processes including oxidation, hydration, and polymerization [7].

The advantages of these catalysts are various structures, several oxidation states, and almost metals in periodic table can be exchanged 
to modify polyoxometalate structures. Polyoxometalate catalyzed pinacol rearrangement was carried out in both homogeneous and heterogeneous system, thus the typical acidity of catalyst is depending on medium reaction. Recently, Uchida et al. [8] reported ionic crystals based on polyoxometalate could catalyze pinacol rearrangement to pinacolone due to $p$-p stacking interaction in the crystal structure and act as an acid species. In the previous reports, study of acid catalyzed pinacol to pinacolone rearrangement is focuses only for acid can catalyzed the rearrangement without deeply search the kind of acid. Thus in this research we emphasized the topic of pinacol to pinacolone rearrangement deeply by evaluate the kind of acid. The aim of the present work was to study acid type in pinacol rearrangement using polyoxometalate catalysts. Polyoxometalates $\mathrm{K}_{4}\left[\mathrm{a}-\mathrm{SiW}_{12} \mathrm{O}_{40}\right]$ and $\mathrm{H}_{4}[\mathrm{a}$ $\left.\mathrm{SiW}_{12} \mathrm{O}_{40}\right]$ as shown in Figure 1 are used in wide range area as catalyst but the reaction medium is play important rule to obtain high yield of product. In this research, toluene as medium to pinacol rearrangement using polyoxometalate catalyst was used.

\section{Materials and Methods}

All starting materials were used directly after purchased without further purification i.e. sodium tungsten, sodium metasilicate, hydrochloric acid, pinacol were from Kanto. Diethyl ether and naphthalene were from Merck. The polyoxometalate $\mathrm{K}_{4}\left[\mathrm{a}-\mathrm{SiW}_{12} \mathrm{O}_{40}\right]$ and $\mathrm{H}_{4}[\mathrm{a}$ $\mathrm{SiW}_{12} \mathrm{O}_{40}$ ] were synthesized according to Téze and Herve [9]. The $\mathrm{KBr}$ pellet was used for sample preparation and FTIR Shimadzu $8201 \mathrm{PC}$ was used to characterize the sample at wavenumber 400-4000 $\mathrm{cm}^{-1}$. ${ }^{1} \mathrm{H}$ NMR Jeol 400 $\mathrm{MHz}$ was used to investigate the existence of proton in polyoxometalate and sample was dissolved in $\mathrm{D}_{2} \mathrm{O}$ as solvent. Monitoring reaction was performed using gas chromatography (GC)

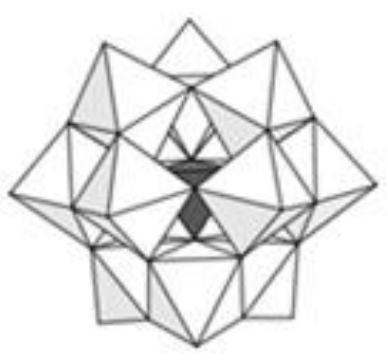

(a)

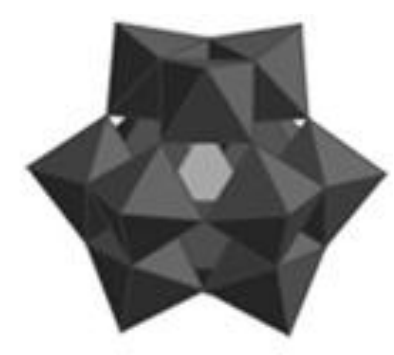

(b)
Figure 1. Polyoxometalates (a). $\mathrm{K}_{4}\left[\mathrm{a}-\mathrm{SiW}_{12} \mathrm{O}_{40}\right]$ and (b). $\mathrm{H}_{4}\left[\mathrm{a}-\mathrm{SiW}_{12} \mathrm{O}_{40}\right][9]$
Perkin Elmer with FID detector and TC-Wax column. GC-MS was carried out using GC-MS Shimadzu 2010QP.

\subsection{Synthesis and Characterization of $K_{4}$ [a-SiW $\left.{ }_{12} \mathrm{O}_{40}\right]$}

Sodium metasilicate (11 g, $50 \mathrm{mmol})$ was dissolved into $100 \mathrm{ml}$ of water (solution A). Sodium tungstate (182 $\mathrm{g}, 0.55 \mathrm{~mol})$ was dissolved into $300 \mathrm{ml}$ of boiling water (solution B). A solution of $4 \mathrm{M} \mathrm{HCl}(165 \mathrm{ml})$ was added drop by drop over 5 min with vigorous stirring in order to dissolve the local precipitate of tungstic acid. Then solution A was added quickly to solution $\mathrm{B}$ followed by adding $50 \mathrm{ml}$ of $4 \mathrm{M} \mathrm{HCl}$. The $\mathrm{pH}$ is around 5 to 6 . The solution was kept at 373 $\mathrm{K}$ for 1 hour. A solution of $1 \mathrm{M}$ sodium tungstate $(50 \mathrm{ml}, 50 \mathrm{mmol})$ and immediately thereafter, $80 \mathrm{ml}$ of $4 \mathrm{M} \mathrm{HCl}$ were added. The solution was filtered after cooling to room temperature. The potassium salt was obtained by adjusting $\mathrm{pH}$ to around 2 with aqueous $1 \mathrm{M} \mathrm{KOH}$, and then solid $\mathrm{KCl}(50 \mathrm{~g})$ was added. White precipitate of $\mathrm{K}_{4}\left[\mathrm{a}-\mathrm{SiW}_{12} \mathrm{O}_{40}\right]$ was obtained. $\mathrm{K}_{4}\left[\mathrm{a}-\mathrm{SiW}_{12} \mathrm{O}_{40}\right]$ was characterized using FT-IR spectrophotometer.

\subsection{Transformation and Characterization of $\mathrm{K}_{4}\left[\mathrm{a}-\mathrm{SiW}_{12} \mathrm{O}_{40}\right.$ ] to $\mathrm{H}_{4}$ [a-SiW ${ }_{12} \mathrm{O}_{40}$ ] [10].}

Transformation of $\mathrm{K}_{4}\left[\mathrm{a}-\mathrm{SiW}_{12} \mathrm{O}_{40}\right]$ to $\mathrm{H}_{4}$ [a$\mathrm{SiW}_{12} \mathrm{O}_{40}$ ] was carried out by ion exchange concept. Solid material of $\mathrm{K}_{4}\left[\mathrm{a}-\mathrm{SiW}_{12} \mathrm{O}_{40}\right](50 \mathrm{~g})$ was dissolved in $100 \mathrm{ml}$ water. Hydrochloric acid was added slowly in the solution of $\mathrm{K}_{4}[\mathrm{a}$ $\mathrm{SiW}_{12} \mathrm{O}_{40}$ ] until volume of hydrochloric acid 50 $\mathrm{ml}$. The mixture was dropped into separation funnel and $50 \mathrm{ml}$ of diethyl ether was added. The mixture was extracted and the polyoxometalate layer was collected and evaporated. White crystal of $\mathrm{H}_{4}$ [a-SiW $\mathrm{Si}_{12} \mathrm{O}_{40}$ ] was obtained after evaporation which was purified using water in several times. Polyoxometalate $\mathrm{H}_{4}[\mathrm{a}$ $\mathrm{SiW}_{12} \mathrm{O}_{40}$ ] was characterized using FT-IR spectrophotometer and ${ }^{1} \mathrm{H}$ NMR in $\mathrm{D}_{2} \mathrm{O}$ as solvent.

\subsection{Rearrangement of Pinacol to Pina- colone}

Rearrangement pinacol to pinacolone was carried out in reaction tube equipped with seal and magnetic stirring. Detail procedure as follows: Into a reaction tube were successively placed pinacol (46.5 mg, $0.394 \mathrm{mmol}$ ), naphthalene $(0.023 \mathrm{~g}, 0.18 \mathrm{mmol})$ as internal standard, polyoxometalate as catalyst $(0.0183 \mathrm{mmol})$, and toluene $(3 \mathrm{ml})$. Then nitrogen gas was introduced into the system. The products and yields 
were determined by GC analysis in combination with mass spectroscopy.

\section{Results and Discussion}

\subsection{Characterization of Catalyst}

Polyoxometalates $\mathrm{K}_{4}\left[\mathrm{a}-\mathrm{SiW}_{12} \mathrm{O}_{40}\right]$ is white solid material and water soluble. These potassium polyoxometalate can be easily transformed to $\mathrm{H}_{4}\left[\mathrm{a}-\mathrm{SiW}_{12} \mathrm{O}_{40}\right]$ by simple extraction to form also white solid acid [11]. Polyoxometalate $\mathrm{H}_{4}\left[\mathrm{a}-\mathrm{SiW}_{12} \mathrm{O}_{40}\right]$ is soluble in water and organic solvent such as methanol and ethanol. Polyoxometalate $\mathrm{K}_{4}\left[\mathrm{a}-\mathrm{SiW}_{12} \mathrm{O}_{40}\right]$ and $\mathrm{H}_{4}[\mathrm{a}-$ $\mathrm{SiW}_{12} \mathrm{O}_{40}$ ] unable be distinguished by physical observation, thus spectroscopy such as FTIR and ${ }^{1} \mathrm{H}$ NMR spectroscopies are used to characterizes of polyoxometalate $\mathrm{K}_{4}\left[\mathrm{a}-\mathrm{SiW}_{12} \mathrm{O}_{40}\right]$ and $\mathrm{H}_{4}\left[\mathrm{a}-\mathrm{SiW}_{12} \mathrm{O}_{40}\right]$. The FTIR spectrum of $\mathrm{K}_{4}[\mathrm{a}$ $\left.\mathrm{SiW}_{12} \mathrm{O}_{40}\right]$ and $\mathrm{H}_{4}\left[\mathrm{a}-\mathrm{SiW}_{12} \mathrm{O}_{40}\right]$ is shown in Figure 2.

Characteristics vibration of polyoxometalates $\mathrm{K}_{4}\left[\mathrm{a}-\mathrm{SiW}_{12} \mathrm{O}_{40}\right]$ and $\mathrm{H}_{4}\left[\mathrm{a}-\mathrm{SiW}_{12} \mathrm{O}_{40}\right]$ are appeared at wavelength $980 \mathrm{~cm}^{-1}$ for $\mathrm{W}=\mathrm{O}, 926$ $\mathrm{cm}^{-1}$ for Si-O, $881 \mathrm{~cm}^{-1}$ for W-Oc-W, and 786 $\mathrm{cm}^{-1}$ for W-Oe-W. Both polyoxometalates $\mathrm{K}_{4}[\mathrm{a}$ $\mathrm{SiW}_{12} \mathrm{O}_{40}$ ] and $\mathrm{H}_{4}\left[\mathrm{a}-\mathrm{SiW}_{12} \mathrm{O}_{40}\right.$ ] have similar absorption bands in FTIR spectrum [12]. Although we unable to distinguish the characteristic bands in polyoxometalates $\mathrm{K}_{4}\left[\mathrm{a}-\mathrm{SiW}_{12} \mathrm{O}_{40}\right]$ and $\mathrm{H}_{4}\left[\mathrm{a}-\mathrm{SiW}_{12} \mathrm{O}_{40}\right]$ but from their specific vibration in Figure 2 we can conclude the availability of $\left[\mathrm{a}-\mathrm{SiW}_{12} \mathrm{O}_{40}\right]^{4-}$ species in the white

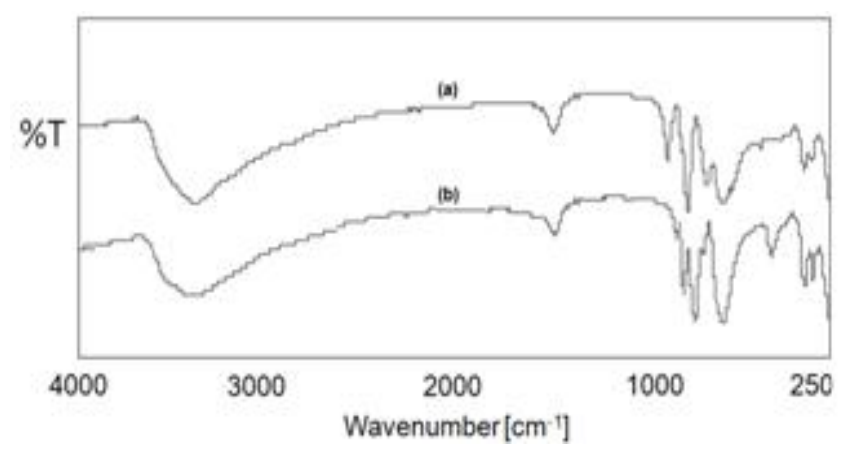

Figure 2. FTIR spectrum of (a). $\mathrm{K}_{4}\left[\mathrm{a}-\mathrm{SiW}_{12} \mathrm{O}_{40}\right]$ and (b). $\mathrm{H}_{4}\left[\mathrm{a}-\mathrm{SiW}_{12} \mathrm{O}_{40}\right]$.

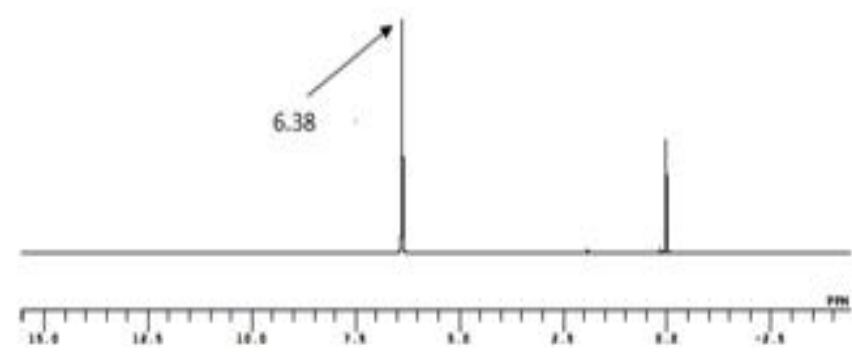

Figure 3. ${ }^{1} \mathrm{H}$ NMR spectrum of $\mathrm{H}_{4}\left[\mathrm{a}-\mathrm{SiW}_{12} \mathrm{O}_{40}\right]$ solid material of polyoxometalates. In order to know the potassium salt or acid properties in polyoxometalates $\mathrm{K}_{4}\left[\mathrm{a}-\mathrm{SiW}_{12} \mathrm{O}_{40}\right]$ and $\mathrm{H}_{4}[\mathrm{a}$ $\mathrm{SiW}_{12} \mathrm{O}_{40}$ ], the measurement using ${ }^{1} \mathrm{H}$ NMR is vital. Spectrum ${ }^{1} \mathrm{H}$ NMR of polyoxometalates $\mathrm{H}_{4}\left[\mathrm{a}-\mathrm{SiW}_{12} \mathrm{O}_{40}\right]$ is shown in Figure 3.

Spectrum ${ }^{1} \mathrm{H}$ NMR polyoxometalates $\mathrm{H}_{4}$ [a$\left.\mathrm{SiW}_{12} \mathrm{O}_{40}\right]$ in $\mathrm{D}_{2} \mathrm{O}$ as a solvent indicated single peak at $6.38 \mathrm{ppm}$ which has contribution from proton in polyoxometalate $\mathrm{H}_{4}\left[\mathrm{a}-\mathrm{SiW}_{12} \mathrm{O}_{40}\right]$. These results showed that four proton in polyoxometalate $\mathrm{H}_{4}\left[\mathrm{a}-\mathrm{SiW}_{12} \mathrm{O}_{40}\right.$ ] are equivalent in the structure of $\left[\mathrm{a}-\mathrm{SiW}_{12} \mathrm{O}_{40}\right]^{4-}$ and act as Brönsted acid [13], while no ${ }^{1} \mathrm{H}$ NMR spectrum was observed for polyoxometalate $\mathrm{K}_{4}\left[\mathrm{a}-\mathrm{SiW}_{12} \mathrm{O}_{40}\right]$ due to no proton peak in the chemical shift from 1-15 ppm as shown in Figure 4. Brönsted acid can be distinguished clearly using both ${ }^{1} \mathrm{H}$ NMR spectrum in Figures 3 and 4.

\subsection{Pinacol rearrangement to pinacolon using polyoxometalate as catalyst}

Polyoxometalates $\mathrm{K}_{4}\left[\mathrm{a}-\mathrm{SiW}_{12} \mathrm{O}_{40}\right]$ and $\mathrm{H}_{4}[\mathrm{a}$ $\mathrm{SiW}_{12} \mathrm{O}_{40}$ ] were used as catalysts in pinacol rearrangement to pinacolone in toluene as medium. As described in the introduction, catalysis using polyoxometalate is depending on the reaction medium [14]. Medium can be selected from inorganic to organic solvent with polarity wide range area. The results of pinacol rearrangement using polyoxometalate $\mathrm{K}_{4}[\mathrm{a}-$ $\left.\mathrm{SiW}_{12} \mathrm{O}_{40}\right]$ and $\mathrm{H}_{4}\left[\mathrm{a}-\mathrm{SiW}_{12} \mathrm{O}_{40}\right]$ is shown in Ta-

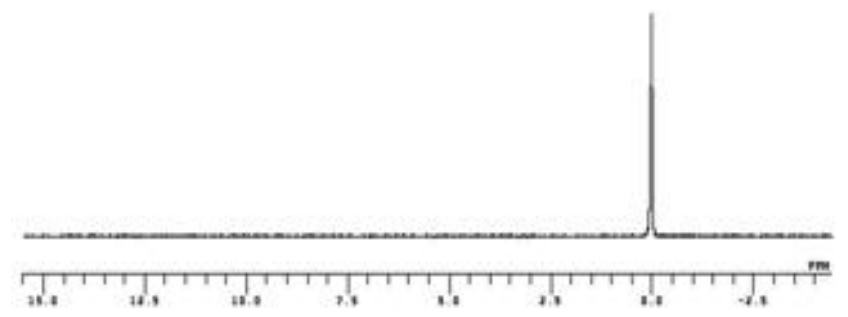

Figure 4. ${ }^{1} \mathrm{H}$ NMR spectrum of $\mathrm{K}_{4}\left[\mathrm{a}-\mathrm{SiW}_{12} \mathrm{O}_{40}\right]$

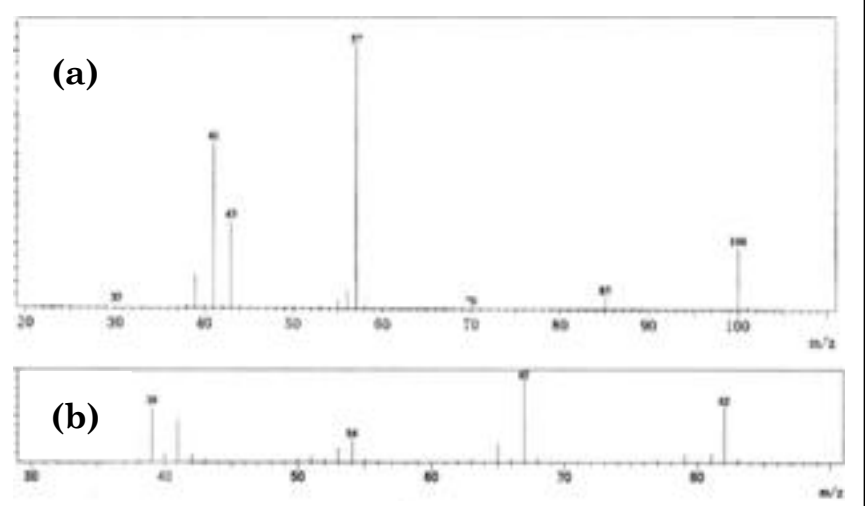

Figure 6. Mass spectrum of (a).pinacolone and (b). 2,3-dimethyl-1,3-butadiene. 


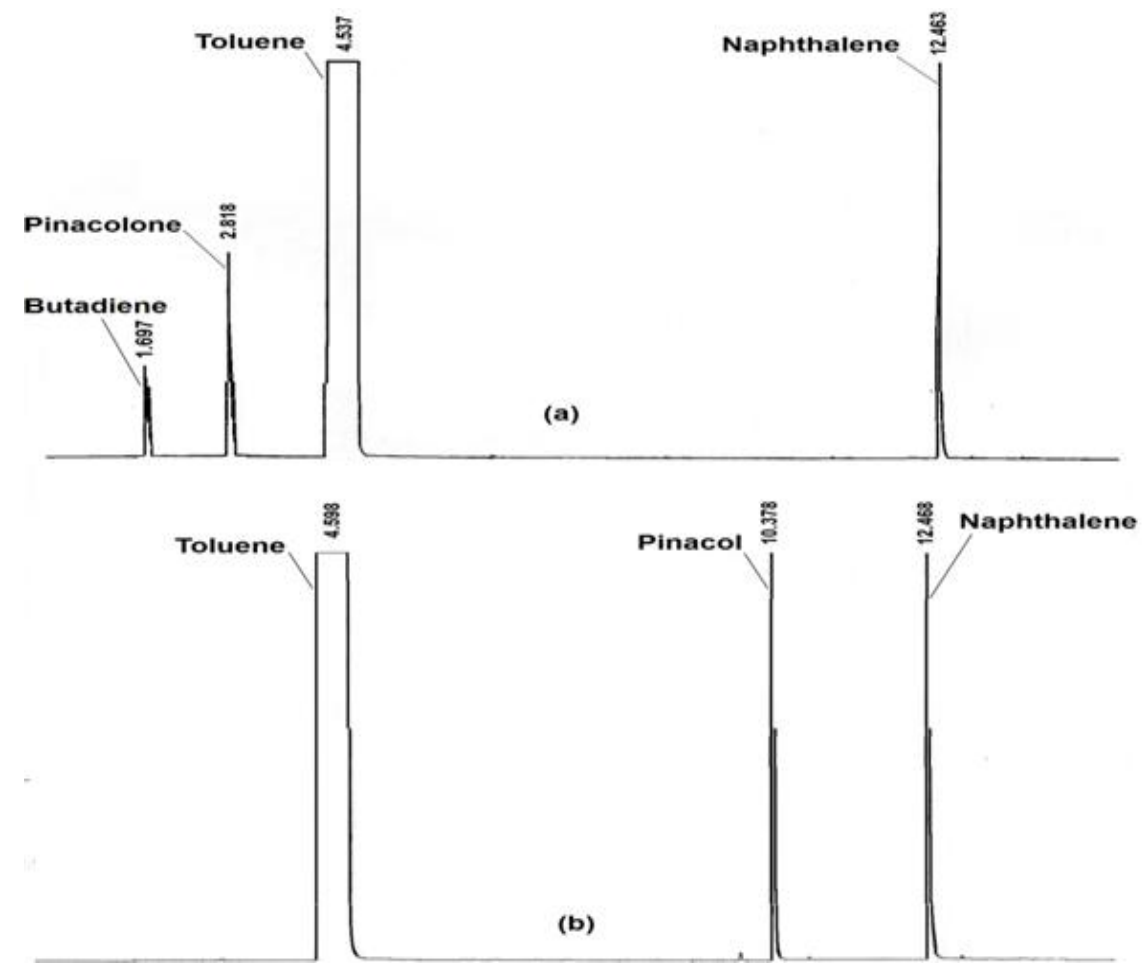

Figure 5. Chromatogram of pinacol rearrangement using polyoxometalates catalyst (below: at initial reaction, above: at $1 \mathrm{~h}$ reaction time).

Table 1. Pinacol rearrangement using polyoxometalates catalyst.

\begin{tabular}{cccccc}
\hline Entry & Catalyst & $\begin{array}{c}\text { Reaction } \\
\text { time }(\mathrm{h})\end{array}$ & $\begin{array}{c}\text { Conversion } \\
(\%)^{\mathrm{a}}\end{array}$ & $\begin{array}{c}\text { Selectivity to } \\
\text { pinacolone (\%) }\end{array}$ & $\begin{array}{c}\text { Selectivity to 2,3- } \\
\text { dimethyl-1,3-butadiene } \\
(\%)^{\mathrm{a}}\end{array}$ \\
\hline 1 & $\mathrm{~K}_{4}\left[\mathrm{a}-\mathrm{SiW}_{12} \mathrm{O}_{40}\right]$ & 1 & 0 & 0 & 0 \\
2 & $\mathrm{~K}_{4}\left[\mathrm{a}-\mathrm{SiW}_{12} \mathrm{O}_{40}\right]$ & 10 & 0 & 0 & 0 \\
3 & $\mathrm{~K}_{4}\left[\mathrm{a}-\mathrm{SiW}_{12} \mathrm{O}_{40}\right]$ & 20 & 0 & 0 & 0 \\
4 & $\mathrm{H}_{4}\left[\mathrm{a}-\mathrm{SiW}_{12} \mathrm{O}_{40}\right]$ & 1 & 100 & 72 & 27 \\
\hline
\end{tabular}

Reaction condition: temperature $373{ }^{\circ} \mathrm{K}$, toluene $3 \mathrm{ml}$, catalyst $0.0183 \mathrm{mmol}$, naphthalene $0.18 \mathrm{mmol}$, pinacol 0.394 mmol. (a) Percentage was determined using GC in combination with GC-MS. GC condition: detector FID, TC-WAX capillary column with internal diameter $0.25 \mathrm{~mm}$ and length $30 \mathrm{~m}$.

ble 1 with chromatogram in Figure 5. The results shows polyoxometalate $\mathrm{K}_{4}\left[\mathrm{a}-\mathrm{SiW}_{12} \mathrm{O}_{40}\right]$ did not have catalytically active properties for pinacol rearrangement. The extent reaction time until $20 \mathrm{~h}$ also did not give pinacolone as main product. By the same condition with polyoxometalate $\mathrm{K}_{4}\left[\mathrm{a}-\mathrm{SiW}_{12} \mathrm{O}_{40}\right]$ we change the catalyst using polyoxometalate $\mathrm{H}_{4}\left[\mathrm{a}-\mathrm{SiW}_{12} \mathrm{O}_{40}\right]$. The results showed that at $1 \mathrm{~h}$ conversion of pinacol is reached $100 \%$. Percentage of conversion and selectivity were calculated base on equation in scheme 1. Identification using GC in Figure 5 indicated of pinacolone and butadiene were found as products in the reaction system. The main product with $\mathrm{m} / z 100$ is pinacolone and another is 2,3-dimethyl-1,3-

$$
\% \text { Conversion }=\frac{\left[A_{0}-A_{\mathrm{t}}\right]}{A_{0}} \times 100 \%
$$

$\%$ Yield $=$

$$
\begin{aligned}
& \frac{[\text { Amount of product }]}{[\text { Total amount of reactant and product }]} \times 100 \% \\
& \% \text { Selectivity }=\frac{[\% \text { Yield }]}{[\% \text { Conversion }]} \times 100 \%
\end{aligned}
$$

Scheme 1. Equation for calculation \% conversion and \% selectivity for pinacol to pinacolone rearrangement. $A_{0}=$ initial amount of reactant; $A_{t}=$ remaining amount of reactant 


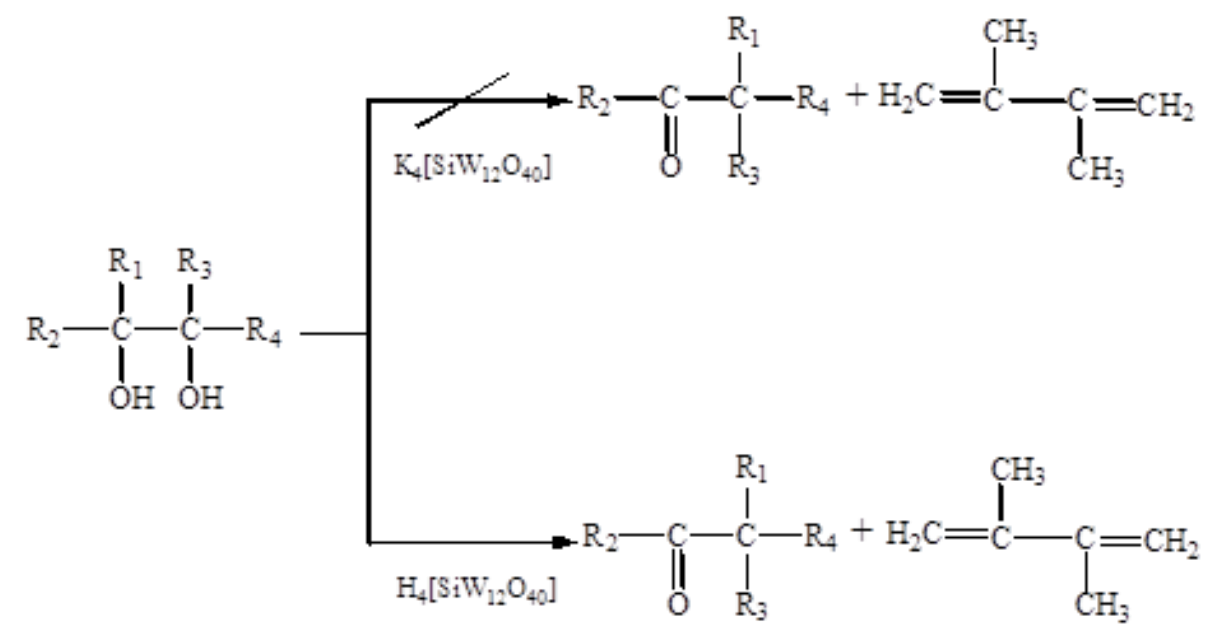

Scheme 2. Pinacol rearrangement by polyoxometalates catalyst.<smiles>C[C@@H]([CH+][CH+]CC(=O)C(C)(C)C)C(C)(O)C(C)(C)O</smiles>

Scheme 3. Pinacol to pinacolone rearrangement using Brönsted acid [2].

butadiene with $m / z 82$. Figure 6 shows the fragmentation pattern of these two products.

Calculation of peak area of two products resulted $72 \%$ yield for pinacolone and $27 \%$ for 2,3 -dimethyl-1,3-butadiene. It was found that carbon balance for these catalytic reactions is $99 \%$, which indicated the equilibrium mass of reactant to product. All results showed that pinacol rearrangement to pinacolone was carried out using Brönsted acid catalyst from polyoxometalate $\mathrm{H}_{4}\left[\mathrm{a}-\mathrm{SiW}_{12} \mathrm{O}_{40}\right]$ and summarized in Scheme 2 with total reaction in Scheme 3.

\section{Conclusions}

The Polyoxometalate $\mathrm{K}_{4}\left[\mathrm{a}-\mathrm{SiW}_{12} \mathrm{O}_{40}\right]$ can be transformed to $\mathrm{H}_{4}\left[\mathrm{a}-\mathrm{SiW}_{12} \mathrm{O}_{40}\right]$ by ion exchange method. Polyoxometalate $\mathrm{K}_{4}\left[\mathrm{a}-\mathrm{SiW}_{12} \mathrm{O}_{40}\right]$ did not active for pinacol rearrangement. Polyoxometalate $\mathrm{H}_{4}\left[\mathrm{a}-\mathrm{SiW}_{12} \mathrm{O}_{40}\right]$ showed its catalytic activity for pinacol rearrangement to pinacolone with formation of 2,3-dimethyl-1,3butadiene as byproduct. The pinacolone was $72 \%$ yield and $27 \%$ byproduct. The reaction system is stable due to stability of carbon balance in the reaction until $99 \%$.

\section{Acknowledgments}

We thank to Department of Chemistry, FMIPA, Sriwijaya University for supporting laboratory facility for this research.

\section{References}

[1] Campelo, J.M., Chakraborty, R., Marinas, J.M., Romero, A.A. (1998). Gas-Phase Pinacol Conversion on $\mathrm{AlPO}_{4}$, g- $\mathrm{Al}_{2} \mathrm{O}_{3}$ and $\mathrm{SiO}_{2}$ Catalysts. Catalysis Letters, 54: 91-93.

[2] Nakamura, K., Osamura, Y. (1993). Theoretical Study of the Reaction Mechanism and Migratory Aptitude of the Pinacol Rearrangement. Journal of The American Chemical Society, 115: 9112-9120.

[3] Loeser, E., Chen, G.P., He, T., Prasad, K., Repiê, O. (2002). Mechanism of the PinacolPinacolone Rearrangement of 2,3-di-(3pyridyl)-2,3-butanediol in Sulfuric Acid. Tetrahedron Letters, 43: 2161-2165.

[4] Hsu, B.Y., Cheng, S. (1998). Pinacol Rearrangement over Metal-Substituted Aluminophosphate Molecular Sieves. Microporous and Mesoporous Materials, 21:505-515.

[5] Bezouhanova, C.P., Jabur, F.A. (1994). Zeolite Catalysts for Pinacol Rearrangement. Journal of Molecular Catalysis, 87: 39-46. 
[6] Toyoshi, Y., Nakato, T., Tamura, R., Takahashi, H., Tsue, H., Hirao, K.I.,Okuhara, T. (1998). Solid-Solid Catalysis by Ultrafine Crystallites of heteropoly Compound for Pinacol Rearrangement. Chemistry Letters, 27(2): $135-136$.

[7] Kamata, K., Nakagawa, Y., Yamaguchi, K., Mizuno, N. (2004). Efficient, Regioselective Epoxidation of Dienes with Hydrogen Peroxide Catalyzed by $\left[\mathrm{g}-\mathrm{SiW}_{10} \mathrm{O}_{34}\left(\mathrm{H}_{2} \mathrm{O}\right)_{2}\right]^{4-}$. Journal of Catalysis, 224: 224-228.

[8] Uchida, S., Lesbani, A., Ogasawara, Y., Mizuno, N. (2012). Ionic Crystals $\left[\mathrm{M}_{3} \mathrm{O}\left(\mathrm{OOCC}_{6} \mathrm{H}_{5}\right)_{6}\left(\mathrm{H}_{2} \mathrm{O}\right)_{3}\right]_{4}\left[\mathrm{a}-\mathrm{SiW}_{12} \mathrm{O}_{40}\right]$ $(\mathrm{M}=\mathrm{Cr}, \mathrm{Fe})$ as Heterogeneous Catalysts for Pinacol Rearrangement. Inorganic Chemistry, 51: 775-777.

[9] Tézé, A., Herve, G. (1990). a-,b-, and gDodecatungstosilicic Acids: Isomers and Related Lacunary Compounds. Inorganic Synthesis, 27: 93-94.
[10] Lesbani, A. (2008). Sintesis dan Karakterisasi Senyawa Polyoxometalate $\mathrm{H}_{4}\left[\mathrm{a}-\mathrm{SiW}_{12} \mathrm{O}_{40}\right]$. Jurnal Penelitian Sains, 11(1): 429-434. (in Indonesian)

[11] Yamase, T., Pope, M.T. (2002). Polyoxometalate Chemistry for Nano-Composite Design; Kluwer: Dordrecht.

[12] Peter, R.G., James, A. de H. (2007). Fourier Transform Infrared Spectrometry, John Wiley and Sons. Page 421-422.

[13] Zhiwu, Y., Qiang, W., Lei, C., Feng, D. (2012). Brønsted/Lewis Acid Sites Synergy in HMCM-22 Zeolite Studied by ${ }^{1} \mathrm{H}$ and ${ }^{27} \mathrm{Al} \mathrm{DQ}$ MAS NMR Spectroscopy. Chinese Journal of Catalysis, 33(1): 129-139.

[14] Török, B., Bucsi, I., Beregszászi, T., Kapocsi, I., Molnár, Á. (1996). Transformation of Diols in the Presence of Heteropoly Acids under Homogeneous and Heterogeneous Conditions. Journal of Molecular Catalysis A: Chemical, 107: 305-311. 